\title{
An Assesment of Arsenic Contamination of Tube- well Water in 17 No Ward of Chattogram City, Bangladesh
}

\author{
F.T. Jahara ${ }^{1 *}$, M. Maniruzzaman ${ }^{2}$, M. S. Shah ${ }^{2}$ \\ ${ }^{1}$ Lecturer,Department of Civil Engineering,Southern University Bangladesh \\ ${ }^{2}$ Student,Department of Civil Engineering,Southern University Bangladesh
}

\begin{abstract}
Arsenic contamination of groundwater has now resulted in world-wide human health problems affecting millions of people across a large number of countries such as India, Pakistan, Thailand, China, Nepal and also in Bangladesh. In 1998-1999, DPHE \& BGS, United Kingdom conducted a study which identified 61 districts out of total 64 in Bangladesh as arsenic affected. In 2008, CUET and the IEBC have been made a joint survey in 41 wards of Chattogram city and they have been found arsenic in shallow tube well water in 13 city wards which exceed WHO guidelines values of $0.01 \mathrm{mg} / \mathrm{l}$ for drinking water. The present study was carried out to identify the Arsenic (As) contaminated tube-wellsin 17 no West BakaliaWard under Chattogram City Corporation. This work was done using HACH EZ Arsenic Test Kit in the field and then compared with Bangladesh Drinking Water Standard $(0.05 \mathrm{mg} / \mathrm{l})$ and WHO guidelines value $(0.01 \mathrm{mg} / \mathrm{l})$. It is revealed from the study that mostly $69.23 \%$ tube-wells are deep and $30.76 \%$ are shallow. Maximum depth of tube-wells is $\mathbf{6 5 0}$ feet and minimum depth is 70 feet. Among 169 samples, Arsenic is detected in $2.36 \%$ water samples and remaining $97.64 \%$ are Arsenic free. The maximum value of arsenic is found in the range of $0.25 \sim 0.05 \mathrm{mg} / \mathrm{l}$ at Police Bit, Rahatturpul area.
\end{abstract}

Keywords: Arsenic; Chattogram, Tube-well; Field test kit; Bangladesh Drinking water standard; WHO guideline.

\section{INTRODUCTION}

A rsenic is a ubiquitous element in the nature and widely distributed in air, water, soils, rocks, plants and animals in variable concentrations. Arsenic is toxic substance to human health and toxicity depends on the amount of arsenic intake, which is classified into acute, sub-acute and chronic toxicity respectively. Skin lesions, i.e. diffuse melanosis followed by spotted melanosis, hyperpigmentation, and keratosis, are common and are the first recognized health effects [1].Most of the ingested arsenic is excreted from the body through urine, stool, skin, hair, nail and breath. In excessive intake, some amount of arsenic is accumulated in tissues and inhibits cellular enzyme activities. Inhalation, ingestion and skin contact are the primary routes of human exposure to the arsenic. Chronic arsenic ingestion from drinking water is known to cause skin cancer, and there is substantial evidence that it increases risk for cancers of the bladder, lung, kidney, liver, colon, and prostate[2].
Arsenic pollution of ground water resources threatens the health of millions of people, particularly in the densely populated river deltas of the Southeast Asia. Major alluvial and deltaic plains and inland basins of Southeast Asia composed of young sediments (Quternary; thousands to tens of thousands of years old) are particularly prone to developing groundwater arsenic problems[3].Bangladesh has been facing issues with arsenic in the groundwater for decades. In 1993, the first case of arsenic poisoning was detected in Dhaka Community Hospital. In 1997, the first national-scale map of Arsenic concentration in Bangladesh's groundwater was produced which showed that $45 \%$ of the areas of Bangladesh had arsenic concentrations greater than $50 \mathrm{mg} / \mathrm{l}$ which exceeded national standard[4].The presence of arsenic contamination throughout Bangladesh is extensive, as evidenced through the findings in 1998, where 41 of the 64 districts in Bangladesh had concentrations of arsenic in groundwater exceeding $50 \mathrm{mg} / \mathrm{l}$. By 2005, another study reported that 50 of 64 districts in Bangladesh had groundwater arsenic concentrations exceeding $50 \mathrm{mg} / \mathrm{l}$ [5].

In the year 1998 and 1999, British Geological Survey (BGS) and Department of Public Health Engineering (DPHE), Bangladesh conducted a national hydro chemical survey of well water in Bangladesh and found alarming amount of arsenic contamination in ground water of Bangladesh. Considering the Bangladesh standard limit of arsenic in drinking water $(0.05 \mathrm{mg} / \mathrm{l})$, about $27 \%$ of all shallow tube wells installed in 61 plain districts of Bangladesh could be remarked as contaminated with arsenic. The Corresponding figures for deep tube wells sunk to a depth of 150 meters and above, were $5 \%$ and $1 \%$ for arsenic contamination of 0.01 $\mathrm{mg} / \mathrm{l}$ and $0.05 \mathrm{mg} / \mathrm{l}$, respectively. It was widely believed that Bangladeshi peoples were getting exposure to arsenic because of the extensive use of arsenic contaminated groundwater for drinking and irrigation purposes since the 1960s. But the major cities in Bangladesh such as Chattogram were not covered by the survey, though groundwater is extensively used in these cities Consequently, in 2008 Chattogram University of Engineering \& Technology (CUET) and the Institution of Engineers Bangladesh, Chattogram Centre (IEBC) jointly conducted a samples survey in Chattogram City Corporation (CCC) area where 41 numbers of ward 
(administrative sub-divisions) are located [6]. From the CUET-IEBC survey, arsenic had been found in shallow tubewells of 13 city wards, of which 7 wards exceeded Bangladesh standard values of $0.05 \mathrm{mg} / \mathrm{l}$ for drinking water and marked as red zones. Among these 7 alarming wards, the maximum arsenic concentration $(0.3 \sim 0.4 \mathrm{mg} / \mathrm{l})$ was found in wardno 17 (West Bakalia)and 40\% tubewells were affected with arsenic[6]. However, that study did not cover all tubewells of the affected ward, only ten samples of each ward of Chattogram city were collected and analysed. So, this study aims to assess all tubewell water of 17 no ward to investigate the present status of arsenic contamination of ward no 17 which is named as West Bakalia ward.

\section{Objectives of the Study:}

The specific objectives of this study are:

$>$ To determine arsenic concentration in all shallow tube wells water in the studied area.

$>$ To compare the results of arsenic concentration level with WHO guide line value $0.01(\mathrm{mg} / \mathrm{l})$ and Bangladesh standard $0.05(\mathrm{mg} / \mathrm{l})$.

$>$ To identify existing arsenic contaminated zones in the studied area.

\section{Study Area:}

Ward no 17 named West Bakalia ward is selected as the Study area which is surrounded by East Bakalia (No.18), East Sholoshor (No.6), Sholokbohor (No.8), South Bakalia (NO.19), and Dewanbazar (No.20). Total area of this ward is 2.56 sq.km where approximately 2, 35,000 inhabitants are living and the literacy rate of the inhabitants is about $64.57 \%$. Considering a huge number of people using water from tube well, assessing quality of water becomes very important. The location of the ward including shallow and deep tube well location has been illustrated in Fig 1.

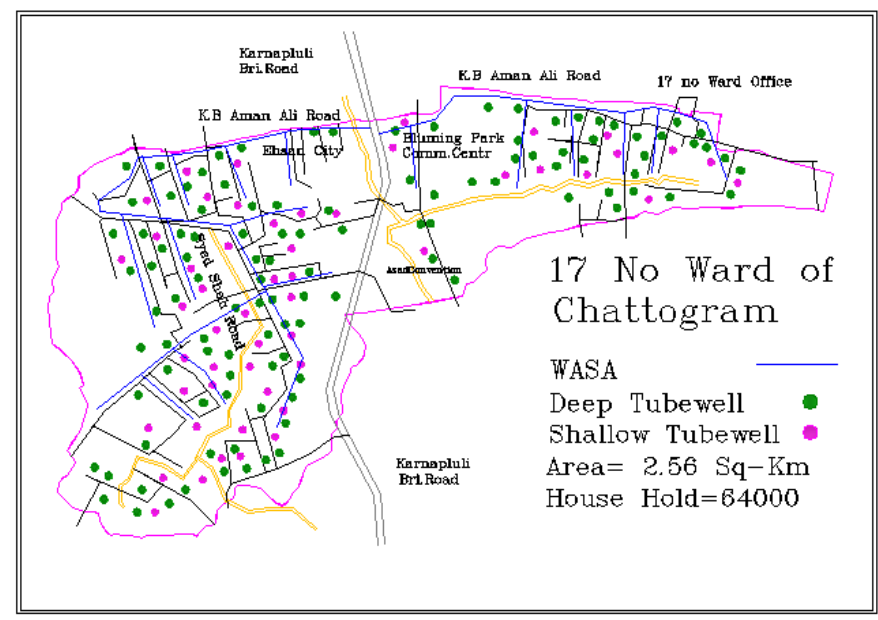

Fig: 1 Study Area Map of 17 No West Bakalia Ward of Chattogram

\section{METHODOLOGY}

Definition of Shallow \& Deep Tubewells

According to "CUET and IEBC" paper [7], the definition of shallow and deep tube wells are:

\section{Shallow Tubewells}

Local people in general consider a tube-well as shallow, when the well diameter is about 1.5 inch (about $38 \mathrm{~mm}$ ) and the depth is less so that water from it can be extracted manually by hand pump. In Chattogram, generally, shallow tube-wells find water within a maximum depth of $150 \mathrm{ft}$. (about 46 meters).

\section{Deep Tube-Wells}

Tube-wells sunk in deep aquifer, having a diameter greater than 1.5 inch, depth greater than the average tube-well and when motorized pumps are used for extracting water, the tube-wells are termed as deep tube-well. Deep tube-wells sunk in deep aquifer, on the other hand, have a varying depth of about 200 feet to 700 feet (about 60 to 215 meters).

In this study, tube-wells exceeding the depth of $150 \mathrm{ft}$ and having a diameter above 1.5 inch are considered as deep tube wells.

\section{Collection of Water Sample}

Water sample were collected in $250 \mathrm{ml}$ mineral water bottles. About 170 empty bottles were collected, washed and dried. The bottles were washed again with the sample water before collection of the sample. The water was then tested in the field using HACH EZ Arsenic Test Kit. A number of field test kits are available in the market. HACH EZ Arsenic Test Kit was therefore used for field-testing of water samples from the tube-wells.

\section{Field Testing of Water Samples}

The water sample was tested in the field by using HACH EZ Arsenic Test Kit. The kit operated according to the procedures and instructions of the manual provided by the manufacturer. After finding the samples result, the Arsenic concentration level was compared with the WHO guideline value and Bangladesh standard. HACH EZ Arsenic Test Kit and its color chart is shown in figure 2. The arsenic field test picture is shown in figure 3 .
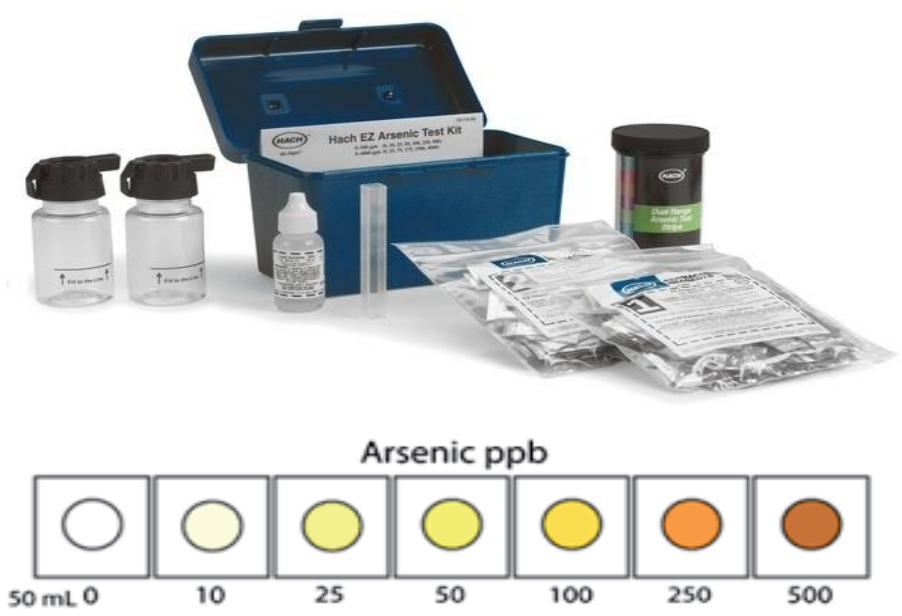

Figure 2: HACH EZ Arsenic Test Kit and Colour Chart 
Fig 3: Arsenic Field Test Picture

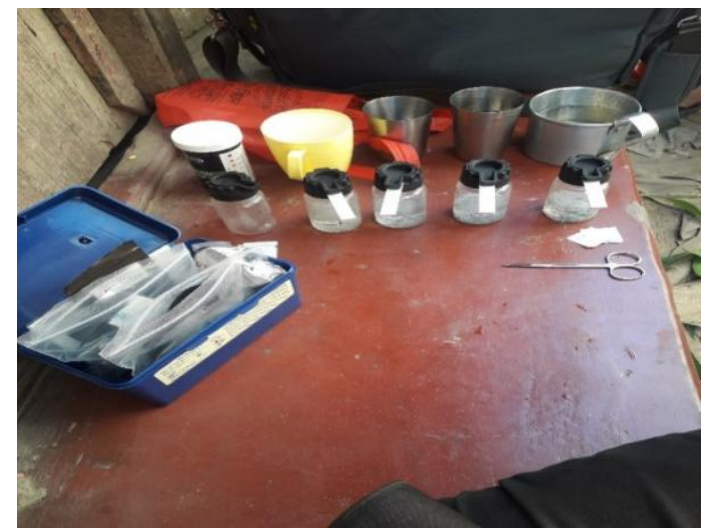

\section{RESULTS}

Arsenic concentration was determined in 17 no ward of Chattogram city. A total of 169 tube wells were assessed for arsenic determination. For each tube well, information about depth and years of use were collected along with the type of tube well and arsenic concentration. Arsenic was determined by $\mathrm{HACH}$ Arsenic Kit. Generally arsenic has not been found in deep tubewells and from this study also it had been found that all deep tubewells (117) were free from arsenic. For this reason, the results of 52 shallow tube wells are shown in Table: 1 below.

Table 1: Arsenic concentration in shallow tubewell:

\begin{tabular}{|c|c|c|c|c|c|c|}
\hline SL No & Tubewell Type & Name of Owner & Location & $\begin{array}{l}\text { Depth } \\
\text { (ft) }\end{array}$ & $\begin{array}{l}\text { Use from the } \\
\text { year }\end{array}$ & Arsenic content (mg/l) \\
\hline 1 & Shallow & Md Siraz & $\begin{array}{l}\text { BogarBill,RasulbagAbasi } \\
\mathrm{k}\end{array}$ & 100 & 2017 & 0 \\
\hline 2 & Shallow & Nurul Hakim & $\begin{array}{l}\text { BogarBill,RasulbagAbasi } \\
\text { k }\end{array}$ & 110 & 2018 & 0 \\
\hline 3 & Shallow & Saiful Colony & $\begin{array}{l}\text { BogarBill,RasulbagAbasi } \\
\mathrm{k}\end{array}$ & 120 & 2010 & 0 \\
\hline 4 & Shallow & NurAkter & $\begin{array}{l}\text { BogarBill,RasulbagAbasi } \\
\mathrm{k}\end{array}$ & 100 & 2017 & 0 \\
\hline 5 & Shallow & MdYeasir & Rasulbag, Block-E & 150 & 2010 & 0 \\
\hline 6 & Shallow & Hasan & $\begin{array}{l}\text { CanmiaMunsir Lane, } \\
\text { Bakalia }\end{array}$ & 100 & 2012 & 0 \\
\hline 7 & Shallow & Ali Neowaz & $\begin{array}{l}\text { CanmiaMunsir Lane, } \\
\text { Bakalia }\end{array}$ & 100 & 2018 & 0 \\
\hline 8 & Shallow & Mohiuddin & $\begin{array}{l}\text { D C Road, Taher Colony } \\
\text { Block }\end{array}$ & 150 & 2010 & 0 \\
\hline 9 & Shallow & Sonet & $\begin{array}{l}\text { D C Road, Taher Colony } \\
\text { Block }\end{array}$ & 120 & 2015 & 0 \\
\hline 10 & Shallow & Yeakub & D C Road, Abu Colony & 120 & 2014 & 0 \\
\hline 11 & Shallow & Hossain & $\begin{array}{l}\text { Chairman Goli, } \\
\text { Santinagar, } \\
\text { BogarBill, } \\
\text { Dewanbazar, }\end{array}$ & 115 & 2015 & 0 \\
\hline 12 & Shallow & Mostofa-1 & $\begin{array}{l}\text { R A Chowdhury Abasik, } \\
\text { Ramzan Ali Chowdhury } \\
\text { Road }\end{array}$ & 150 & 2017 & 0 \\
\hline 13 & Shallow & Mostofa-2 & $\begin{array}{l}\text { R A Chowdhury Abasik, } \\
\text { Ramzan Ali Chowdhury } \\
\text { Road }\end{array}$ & 120 & 2017 & 0 \\
\hline 14 & Shallow & Sahzahan & $\begin{array}{l}\text { Uzir shah Lane, Cherager } \\
\text { Bari }\end{array}$ & 125 & 2012 & 0 \\
\hline 15 & Shallow & SamzKabirMonzil & $\begin{array}{l}\text { Uzir shah Lane, Cherager } \\
\text { Bari }\end{array}$ & 110 & & 0 \\
\hline 16 & Shallow & Kabir & $\begin{array}{l}\text { Uzir shah Lane, Cherager } \\
\text { Bari }\end{array}$ & 95 & 2003 & 0 \\
\hline 17 & Shallow & Nurul Islam & HaziNurSowdagor Bari & 70 & 2004 & 0 \\
\hline 18 & Shallow & Sowkat & HaziNurSowdagor Bari & 80 & 2015 & 0 \\
\hline 19 & Shallow & Mohammad Indris & HaziNurSowdagor Bari & 100 & 2015 & 0 \\
\hline 20 & Shallow & Sekander & HaziNurSowdagor Bari & 150 & 2005 & 0 \\
\hline 21 & Shallow & Mahmuda & $\begin{array}{l}\text { MahmudaBaper Bari, } \\
\text { Rahattarpul }\end{array}$ & 120 & 2008 & 0 \\
\hline 22 & Shallow & Jamir Sowdagor & MahmudaBaper Bari, & 135 & 2018 & $0.01-0.025 \mathrm{mg} / \mathrm{l}$ \\
\hline
\end{tabular}


International Journal of Research and Innovation in Social Science (IJRISS) |Volume V, Issue VII, July 2021|ISSN 2454-6186

\begin{tabular}{|c|c|c|c|c|c|c|}
\hline SL No & Tubewell Type & Name of Owner & Location & $\begin{array}{l}\text { Depth } \\
\text { (ft) }\end{array}$ & $\begin{array}{l}\text { Use from the } \\
\text { year }\end{array}$ & Arsenic content $(\mathrm{mg} / \mathrm{l})$ \\
\hline & & & Rahattarpul & & & \\
\hline 23 & Shallow & Zamal & $\begin{array}{l}\text { MahmudaBaper Bari, } \\
\text { Rahattarpul }\end{array}$ & 115 & 2015 & $0.00-0.010 \mathrm{mg} / \mathrm{l}$ \\
\hline 24 & Shallow & Mostafiz & $\begin{array}{l}\text { MahmudaBaper Bari, } \\
\text { Rahattarpul }\end{array}$ & 120 & 2020 & 0 \\
\hline 25 & Shallow & Monzo & $\begin{array}{l}\text { MahmudaBaper Bari, } \\
\text { Rahattarpul }\end{array}$ & 120 & 2015 & 0 \\
\hline 26 & Shallow & Nasir Colony & $\begin{array}{l}\text { Haziful Rahman lane, } \\
\text { Poraton } 4 \text { Tola }\end{array}$ & 100 & 2012 & 0 \\
\hline 27 & Shallow & Liton Colony & $\begin{array}{l}\text { Haziful Rahman lane, } \\
\text { Poraton } 4 \text { Tola }\end{array}$ & 90 & 2012 & 0 \\
\hline 28 & Shallow & Sirazul Islam & $\begin{array}{l}\text { Haziful Rahman lane, } \\
\text { Poraton } 4 \text { Tola }\end{array}$ & 100 & 2015 & 0 \\
\hline 29 & Shallow & Forkan & $\begin{array}{l}\text { Haziful Rahman lane, } \\
\text { Poraton } 4 \text { 30Tola }\end{array}$ & 120 & 2012 & 0 \\
\hline 30 & Shallow & NurulAbser & $\begin{array}{l}\text { Haziful Rahman lane, } \\
\text { Poraton } 4 \text { 31Tola }\end{array}$ & 120 & 2010 & 0 \\
\hline 31 & Shallow & NurBegam & $\begin{array}{l}\text { Sayad S32hah Road, } \\
\text { Nira32pod Building }\end{array}$ & 150 & 2010 & 0 \\
\hline 32 & Shallow & Surovi Tower & SuroviAbasik & 135 & 2018 & 0 \\
\hline 33 & Shallow & Sopnonil & SuroviAbasik & 130 & 2008 & 0 \\
\hline 34 & Shallow & Haziyusof company & $\begin{array}{l}\text { BoroKoborstan, Yousuf } \\
\text { Company Goli, } \\
\text { Rahattarpul }\end{array}$ & 120 & 2015 & 0 \\
\hline 35 & Shallow & Kasem & $\begin{array}{l}\text { BoroKoborstan, Yousuf } \\
\text { Company Goli, } \\
\text { Rahattarpul }\end{array}$ & 145 & 2017 & 0 \\
\hline 36 & Shallow & Usman goni & $\begin{array}{l}\text { ZorinaBaperBari,Hozorot } \\
\text { Tajuddudin Shah Mosque, } \\
\text { Rahattapul }\end{array}$ & 125 & 2018 & 0 \\
\hline 37 & Shallow & Rezaulkarim & Waziullah Master Bari & 150 & 2010 & 0 \\
\hline 38 & Shallow & KabirSaheb & $\begin{array}{l}\text { Police Bit, } \\
\text { Rahattarpul } \\
\end{array}$ & 110 & 2010 & $0.025-0.050 \mathrm{mg} / \mathrm{l}$ \\
\hline 39 & Shallow & AltafMenson & Mostafa Abasik & 150 & 2004 & 0 \\
\hline 40 & Shallow & Hazera Feles & Mostafa Abasik & 140 & 2012 & 0 \\
\hline 41 & Shallow & KazimulSaifuddin & SalbonAbasik & 110 & 2016 & 0 \\
\hline 42 & Shallow & $\begin{array}{l}\begin{array}{l}\text { Sobor } \\
\text { (SP Colony) }\end{array} \\
\end{array}$ & $\begin{array}{l}\text { Mazar Road (Deputy } \\
\text { road) }\end{array}$ & 60 & 2015 & $0.00-0.010 \mathrm{mg} / \mathrm{l}$ \\
\hline 43 & Shallow & Liton & $\begin{array}{l}\text { Mazar Road (Deputy } \\
\text { road) }\end{array}$ & 150 & 2019 & 0 \\
\hline 44 & Shallow & Munshi Mia & $\begin{array}{l}\text { Mazar Road (Deputy } \\
\text { road) }\end{array}$ & 150 & 2012 & 0 \\
\hline 45 & Shallow & Md. Nasir & Bow Bazar & 250 & 2004 & 0 \\
\hline 46 & Shallow & Md. Kalam & Bow Bazar & 75 & 2016 & 0 \\
\hline 47 & Shallow & Anwar Hossain & Bow Bazar & 85 & 2003 & 0 \\
\hline 48 & Shallow & ShiponHoque & Bow Bazar & 150 & 1999 & 0 \\
\hline 49 & Shallow & AbedaKhatun & Khalpar,Bakalia & 128 & 2008 & 0 \\
\hline 50 & Shallow & KepayetUllah & Khalpar,Bakalia & 100 & 2019 & 0 \\
\hline 51 & Shallow & Iftekhar Ahmed & Khalpar,Bakalia & 90 & 2009 & 0 \\
\hline 52 & Shallow & Golam Mortuza & Khalpar,Bakalia & 95 & 2011 & 0 \\
\hline
\end{tabular}

Water samples from 117 deep tubewells from the study area were collected similarly and similar information as shallow tubewells were gathered for arsenic analysis of all deep tubewells. No arsenic was found in deep tubewells of 17 no ward.

\section{ANALYSIS OF ARSENIC CONTAMINATION}

Arsenic concentration may be grouped into 2 major categories: i) Safe Level (less than $0.05 \mathrm{mg} / \mathrm{l}$ ) ii) Contamination Level (greater than $0.05 \mathrm{mg} / \mathrm{l}$ ). 
Safe level is categorized into three categories: a) 0 b) WHO permissible level $(<0.01 \mathrm{mg} / \mathrm{l})$ and $\mathrm{c})$ BD Standard Maximum Contamination Level MCL $(<0.05 \mathrm{mg} / \mathrm{l})$ [8].These groupings and the results of study area are presented in Table 2.

Table 2: Analysis of Arsenic Concentration

\begin{tabular}{|c|c|c|c|}
\hline Major Group & $\begin{array}{l}\text { Arsenic } \\
\text { Magnitudes } \\
(\mathrm{mg} / \mathrm{l})\end{array}$ & $\begin{array}{l}\text { Detailed } \\
\text { Classifications }\end{array}$ & $\begin{array}{l}\text { Number of } \\
\text { Tube wells }\end{array}$ \\
\hline \multirow[b]{3}{*}{ Safe Level } & 0 & 0 & 165 \\
\hline & $<0.01$ & $\begin{array}{l}\text { WHO } \\
\text { Permissible Limit }\end{array}$ & 2 \\
\hline & $<0.05$ & $\begin{array}{l}\text { Bangladesh } \\
\text { Standard Limit }\end{array}$ & 2 \\
\hline \multirow{3}{*}{$\begin{array}{l}\text { Contamination } \\
\text { Level }\end{array}$} & $0.05-0.1$ & $\begin{array}{l}\text { Moderate } \\
\text { Contamination }\end{array}$ & \multirow{3}{*}{ None } \\
\hline & $0.1-0.3$ & $\begin{array}{l}\text { High } \\
\text { Contamination }\end{array}$ & \\
\hline & $>0.3$ & $\begin{array}{l}\text { Severe } \\
\text { Contamination }\end{array}$ & \\
\hline
\end{tabular}

According to Table 2, arsenic concentration values of all samples of this ward are in safe level (0 to $0.05 \mathrm{mg} / \mathrm{l})$. The results of arsenic analysis are presented in Table 3 below.

Table 3: Results of Arsenic analysis

\begin{tabular}{|l|l|l|l|}
\hline \multicolumn{2}{|l|}{$\begin{array}{l}\text { Deep tubewell } \\
\text { (Above 150 feet depth) }\end{array}$} & \multicolumn{2}{|l|}{$\begin{array}{l}\text { Shallow tubewell } \\
\text { (From EGL to 150 feet depth) }\end{array}$} \\
\hline $\begin{array}{l}\text { No of } \\
\text { tubewell }\end{array}$ & $\begin{array}{l}\text { Value of } \\
\text { Arsenic } \\
\text { (using Kit) }\end{array}$ & $\begin{array}{l}\text { No of } \\
\text { tubewell }\end{array}$ & $\begin{array}{l}\text { Value of Arsenic (using } \\
\text { Kit) }\end{array}$ \\
\hline \multirow{3}{*}{117} & \multirow{3}{*}{$0 \mathrm{mg} / \mathrm{l}$} & 48 & $0 \mathrm{mg} / 1$ \\
\cline { 3 - 4 } & 2 & 1 & $0.00-0.010 \mathrm{mg} / 1$ \\
\cline { 3 - 4 } & & 1 & $0.01-0.025 \mathrm{mg} / 1$ \\
\cline { 3 - 4 } & & $0.025-0.050 \mathrm{mg} / 1$ \\
\hline
\end{tabular}

From the analysis, 165 tubewells of the studied area are free from arsenic, 2 tubewells are within WHO permissible Limit and 2 tubewells exceed WHO standard limit but within Bangladesh Standard Limit. This is represented in percentage form in figure 4 .

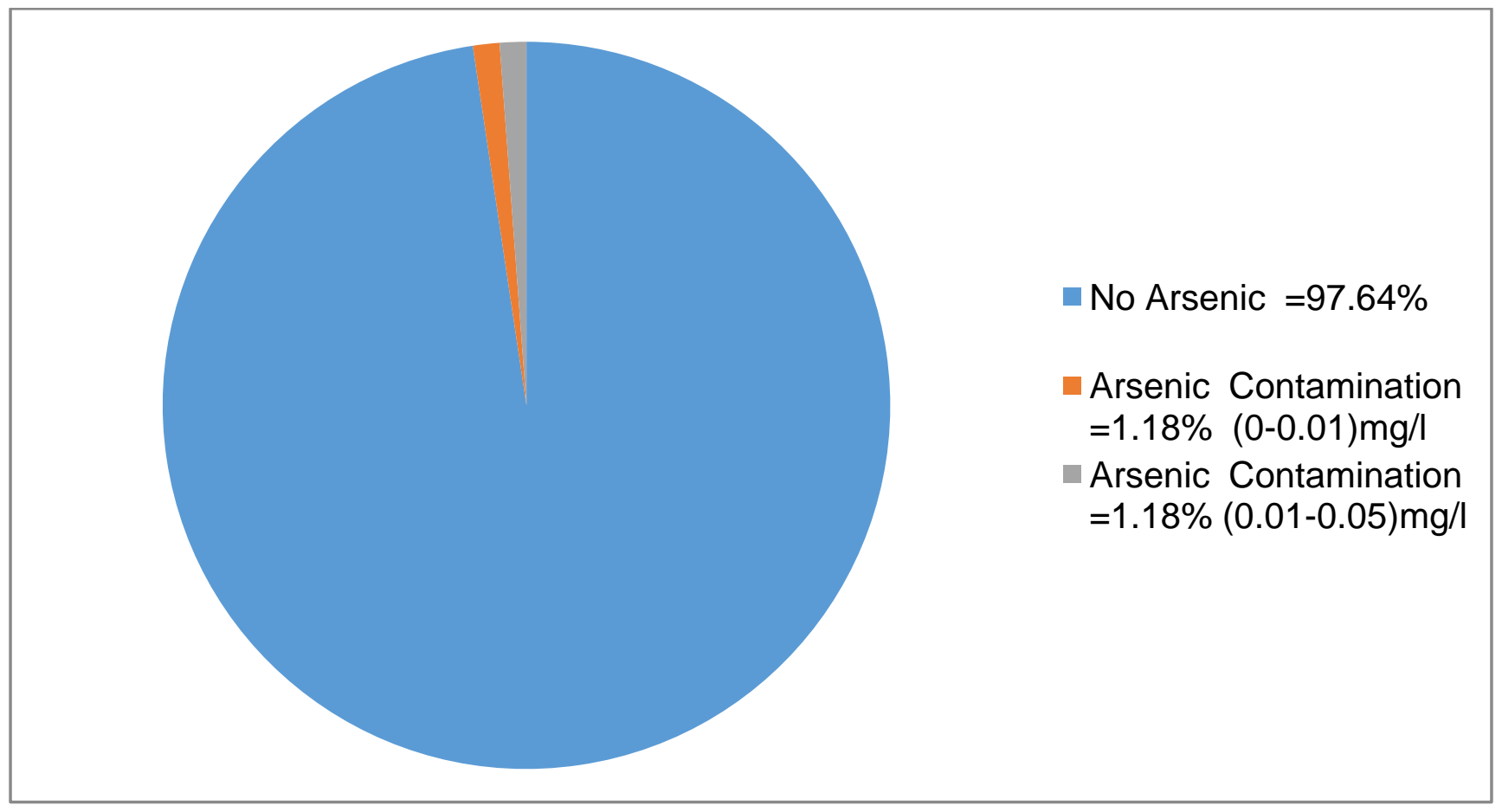

Figure 4: Percentage of Arsenic Analysis

\section{CONCLUSION}

Arsenic is a slow poison. It may take five to fifteen years to reach the last stage of Arsenicosis. Therefore, arsenic test of tubewells must be done at regular intervals. From this arsenic study of 17 no ward of Chattogram city, Arsenic is not found in deep tubewells that means beyond the depth of 46 meter (about 150 feet). Arsenic is found in 4 Tube wells; among these 2 Tube wells are within WHO permissible limit and other 2 Tube wells arsenic value exceed WHO limit but within Bangladesh Standard Limit. The maximum arsenic value is found in the range of $0.25 \sim 0.05 \mathrm{mg} / \mathrm{l}$ in Police Bit,
RahatturPul area. So, people living in this area must make conscious about it. However, we cannot paint red of four tubewells which we found arsenic because the arsenic value did not exceed Bangladesh standard limit $(0.05 \mathrm{mg} / \mathrm{l})$. Moreover, during this study, information about WASA line coverage is gathered. Maximum area is enclosed by WASA at present except the following area:Police Bit (RahattarPul Area), Bagan Bari, Mostafa R/A (RahattarPul Area), half of Rasulbag R/A, half of Sayed Sha Road, Ratter pul A. Khalik, Chan Mia Munshi R/A, BagarBil, Shalbon R/A. Though the percentage of arsenic is quite low (2.36\%) in these area, it is harmful for people consuming tubewell water for their health. 
So, this study recommends that the mentioned area must be under the supply of WASA as early as possible so that people can avoid tubewell water atleast for drinking purpose.

\section{ACKNOWLEDGEMENTS}

The authors would like to acknowledge the help of the authority of Southern University Bangladesh for providing various facilities.

\section{REFERENCES}

[1]. M.F. Hossain, "Arsenic_Contamination_in_Bangladesh_an Overview.pdf." 2005, 26 oct.

[2]. $\bar{M}$ S Islam, EuroAquae(2005-2007), Hydro Informatics and Water Management Program, University, of Newcastle upon Tyne, Department Of Civil Engineering and Geosciences, and F. Islam, Assistant Bacteriologist (2006-2008), Bangladesh, "Arsenic Contamination in Ground water in Bangladesh.pdf."

[3]. S. M. Tareq, S. M. N. Islam, M. M. Rahmam, and D. A. Chowdhury, "Arsenic Pollution in Groundwater of Southeast Asia: an Overview on Mobilization Process and Health Effects," vol. 8, p. 22, 2010.

[4]. Basak, P.1, , Mohee, F.M., 2, and , Freire-Gormaly, M3, "Case study of Arsenic Contamination in Sitakunda District, Chittagong,.pdf." · April 2020, May 07, 2020. [Online]. Available: marina.freire-gormaly@lassonde.yorku.ca

[5]. Fakir Md. Yunus $1,2, \dagger$, Safayet Khan $1, \dagger$, Priyanka Chowdhury 1,†, Abul Hasnat Milton 3, , Sumaira Hussain 3 and Mahfuzar Rahman 1,Fakir Md. Yunus 1,2,†, Safayet Khan 1, $\dagger$, Priyanka Chowdhury 1,†, Abul Hasnat Milton 3, , and Sumaira Hussain 3 and Mahfuzar Rahman 1, "A Review of Groundwater Arsenic Contamination in Bangladesh: The Millennium Development Goal Era and Beyond." 15 February 2016, 15 February.

[6]. M.A. Malek1, , M.N. Uddin2, , M. Atiquzzaman3, , A.H.M.G. Hyder4, and , S.K. Palit, "Arsenic Contamination of Tube Well Water in Chittagong City, Bangladesh- A Case Study.pdf." 5, May-2014.

[7]. M. Ashraf, Arsenic contamination of ground water in our cities: Screening of all the tube wells in North Halishahar Ward, Chittagong. 2011.

[8]. M. Manzurul Hassan, The Spatial Pattern of Risk from Arsenic Poisoning: A Bangladesh Case Study. 